\title{
POVEZANOST SAMOPOŠTOVANJA NASTAVNIKA S PROCJENOM ŠKOLSKOG OZRAČJA
}

\section{SAŽETAK}

\author{
Đurđica HLAPČIĆ, mag. med. techn \\ hlapcic.djurdjica@gmail.com \\ Srednja škola Čakovec \\ Ulica Jakova Gotovca 2 \\ 40000 Čakovec
}

Cilj istraživanja: Ispitati povezanost samopoštovanja nastavnika s njihovom procjenom školskog ozračja (školske klime). Ispitanici i metode: Ispitanici su bili nastavnici Srednje škole Čakovec i Medicinske škole Varaždin. Provedena je presječna studija koja je sveukupno obuhvatila 97 nastavnika. Korišten je anonimni anketni listić koji se sastojao od triju dijelova. Prvi dio ankete prikupljao je demografske podatke, drugi je dio primijenio Hrvatski upitnik školske klime za nastavnike, a treći dio Rosenbergovu skalu samopoštovanja koja sadrži deset tvrdnji o stavovima i osjećajima o samom sebi. Kategorijski podatci predstavljeni su apsolutnim i relativnim frekvencijama. Numerički su podatci opisani aritmetičkom sredinom i standardnom devijacijom u slučaju raspodjela koje slijede normalu, a u ostalim slučajevima medijanom i granicama interkvartilnog raspona. Razlike kategorijskih varijabli testirane su Hi-kvadrat testom, a po potrebi Fisherovim egzaktnim testom. Normalnost raspodjele numeričkih varijabli testirana je Shapiro-Wilkovim testom. Razlike normalno raspodijeljenih numeričkih varijabli između dviju nezavisnih skupina testirane su Studentovim t testom, a $\mathrm{u}$ slučaju odstupanja od normalne raspodjele Mann-Whitneyjevim U testom. Razlike normalno raspodijeljenih numeričkih varijabli između triju i više nezavisnih skupina testirane su analizom varijance (ANOVA), a u slučaju odstupanja od normalne raspodjele Kruskal-Wallisovim testom. Povezanost normalno raspodijeljenih numeričkih varijabli ocijenjena je Pearsonovim koeficijentom korelacije r, a u slučaju odstupanja od normalne raspodjele Spearmanovim koeficijentom korelacije (rho). Pouzdanost skala procijenila se koeficijentom unutarnje konzistentnosti (CronbachAlpha). Sve su P vrijednosti dvostrane. Razina značajnosti postavljena je na Alpha=0,05. Rezultati: Nastavnici s većim samopoštovanjem negativnije procjenjuju školsku klimu, dok oni s manjim samopoštovanjem procjenjuju pozitivnije. Zaključak: Nastavnici s više samopoštovanja imaju više kriterije, traže izazove, manji radni pritisak i inovativne metode rada.

Ključne riječi: nastavnici, samopoštovanje, školsko ozračje, medicinske škole

\section{UVOD}

Istraživanja školske klime/ozračja
intenzivnije započinju šezdesetih godina
prošloga stoljeća, i to uglavnom u
anglofonskim zemljama. U posljednja
četiri desetljeća ova su istraživanja

rezultirala objavljivanjem velikog broja radova u kojima su prikazani rezultati mjerenja različitih aspekata školskog ozračja. Ono što je zajedničko različitim istraživanjima $\mathrm{u}$ ovom području mjerenje 
Đ. Hlapčić, Povezanost samopoštovanja nastavnika s procjenom školskog ozračja

je ozračja na osnovi percepcije, odnosno na osnovi nastavnikovih $\mathrm{i} / \mathrm{ili}$ učenikovih opisa školskog života (Domović, 2003). Svjetski poznati istraživači odgojno-obrazovnog ozračja najčešće upotrebljavaju izraze climate (klima) i psychosocia lenvironment (psihosocijalna okolina) kao sinonime. U domaću literaturu izraz ozračje uvodi Bošnjak 1997., a prihvaćaju ga i drugi autori kao termin za školsko ozračje, razredno-nastavno ozračje ili razredno ozračje. Za izraz klima/ozračje u odgojnoobrazovnom kontekstu nailazimo $\mathrm{u}$ literaturi i u praksi na više istoznačnih termina: atmosfera, klima, ambijent, ugođaj, ton, duh, okolina, okruženje, situacija, kultura, etos, moral. S obzirom na sadržaje ozračja nailazimo na izraze: socijalno, psihosocijalno, psihološko, organizacijsko, intelektualno ozračje, a u odnosu na institucionalnu razinu na koju se odnosi: školsko, razredno i razrednonastavno (Božić, 2015: 93-100). Iako postoje brojne definicije školske klime, može se reći da je većina njih suglasna kako je školska klima na iskustvu zasnovan, multidimenzionalan, relativno trajan percepcijski fenomen zajednički članovima određene škole. Spomenuta percepcija ovisi o tome kako pojedinac doživljava okruženje u školi, primjerice, osjeća li se ugodno u školskom okruženju, je li okruženje suportivno za učenje i poučavanje, je li adekvatno organizirano i sigurno. To znači da ovisno o interesima, vrijednostima, motiviranosti i ostalim karakteristikama pojedinca, školska klima može biti percipirana kao poticajna za individualni razvoj $i$ doprinositi konstruktivnom ponašanju i uključivanju pojedinca $u$ aktivnost škole ili pak suprotno, kao destimulirajući kontekst koji doprinosi pasivnosti, pružanju otpora i agresivnom ponašanju (Puzić, Baranović, Doolan, 2011: 335-358). Psihosocijalno ozračje u nekoj zajednici postalo je predmet znanstvenih istraživanja još $u$ tridesetim godinama 20. stoljeća. Teorijsko polazište za proučavanje odnosa pojedinacokolina nalazi se u Lewinovoj teoriji polja koja ističe međusobnu povezanost pojedinca i okoline. Prema teoriji polja pojedinac živi u svom životnom prostoru ili polju podijeljenom na fizički i psihički koji su međusobno povezani tako da promjene $\mathrm{u}$ jednom polju izazivaju promjene u drugom. Spoznavanje događaja uvjetovano je motivima, osobinama ličnosti, ali $i$ trenutnim događajima $u$ okolini. Ovisno o njihovu utjecaju, govorimo o stvarnom ili poželjnom ozračju (Božić, 2015: 93-100). Najbolji rezultati postižu se onda kad se smišljeno i planski primjenjuju sve metode, kad se one međusobno prožimaju, potpomažu i nadopunjuju. Školski život pruža dosta mogućnosti za navikavanje na kulturno ponašanje, red, disciplinu, urednost, 
točnost, savjesnost, pozitivan odnos prema radu, materijalnim i duhovnim vrednotama (Vukasović, 1998). Za uspješnost učenika u odgojno-obrazovnom procesu slika koju ima o sebi nije manje značajna od njegovih intelektualnih potencijala. Učiteljev smisao za humor te korištenje svakodnevnih situacija iz života $u$ školi da se nasmije sa svojim učenicima, potiču optimizam, vedrinu i smijeh. Radost prati smijeh, a smijeh oslobađa od napetosti (Vlada Republike Hrvatske, 1999). Možda će u objašnjenju pojma aktivno učenje pomoći i pojam inovativno učenje. Taj pojam označava učenje usmjereno prema budućnosti kojem su važan sastavni element anticipacija ili predviđanje (umjesto pasivnog prilagođavanja postojećem) te participacija (aktivno sudjelovanje učenika) (Matijević, 1997: 33-44).

Opća procjena samog sebe (samopoštovanje) sastoji se od dvaju dijelova: osjećaja vlastite vrijednosti i samopouzdanja. Vrlo je važno razlikovati ova dva pojma iako su oni međusobno povezani (Rijavec, Miljković, 2008). Samopoštovanje osnova je mentalnog zdravlja, ustrajnosti nakon neuspjeha te, općenito, pozitivna društvena vrijednost (Kuzijev, Topolovčan, 2013: 125-144).

\section{DOSADAŠNJA ISTRAŽIVANJA}

$\mathrm{Na}$ osnovi istraživanja $\mathrm{u}$ različitim radnim sredinama Moos i Insel (1981. prema Moos, 1986.) razvili su skalu radne okoline (WorkEnvironmentScale - WES). Upotreba ovog instrumenta preporuča se za praćenje i evaluaciju radne klime, kao i pri uvođenju promjena u radnu okolinu. Obuhvatnije istraživanje proveli su Docker, Fisher i Fraser 1984., i to na uzorku od 34 državne i privatne škola, tj. na uzorku od 599 nastavnika. Uzorak je uključivao osnovne $i$ srednje škole te koledže. Ispitanici su odgovarali na dvije forme WES-a, o aktualnu i željenu stanju. Ovo je istraživanje, također, potvrdilo unutarnju konzistentnost i diskriminativnu valjanost instrumenta. Osim toga, utvrđen je značajan stupanj slaganja među nastavnicima $u$ različitim tipovima škola $s$ obzirom na poželjnu školsku klimu. Za razliku od ovog nalaza, pokazale su se značajne razlike među školama $u$ percepciji aktualne klime. Najdojmljiviji nalaz bio je da je klima u osnovnim školama povoljnija u odnosu na druge tipove škola, što se osobito očituje u procjeni većeg stupnja inovativnosti i fizičkog komfora te iskazivanju manjeg radnog pritiska (Domović, 2003). Istraživanje iz 2013. godine kojem je bio cilj, među ostalim, ispitati u kojoj mjeri sociodemografska obilježja učitelja, razlozi izbora učiteljske profesije i razina 
samopoštovanja predviđaju pojavljivanje profesionalnog sagorijevanja na poslu kod učitelja osnovne škole, potvrdilo je kako upravo ti čimbenici (sociodemografska obilježja, razlozi izbora učiteljske profesije i razina samopoštovanja) značajno predviđaju učiteljsko sagorijevanje. Pokazalo se da su muški učitelji, učitelji iz matičnih škola, učitelji koji imaju prebivalište u gradu, učitelji koji nisu zadovoljni izborom učiteljske profesije, učitelji koji očekuju da učiteljska profesija pruža mnogo vremena za obitelj i sigurnost posla, učitelji kojima je učiteljski studij bio drugi izbor studija, učitelji koji imaju nisku intrinzičnu motivaciju i nisku sposobnost poučavanja, učitelji koji smatraju da svojom profesijom imaju slab doprinos društvu te učitelji $\mathrm{s}$ niskim samopoštovanjem pod većim rizikom profesionalnog sagorijevanja na poslu (Kuzijev, Topolovčan, 2013: 125-144). Istraživanje o stvarnom i poželjnom ozračju u osnovnoj školi pokazalo je da postoji statistički značajna razlika u procjeni svih dimenzija stvarnog i poželjnog razrednoga ozračja kod učenika nižih i viših razreda osnovne škole, pri čemu je razlika između stvarnog i poželjnog razrednog ozračja kod učenika četvrtih razreda vrlo velika, kod učenika šestih razreda umjerena, a kod učenika osmih razreda ta je razlika povećana $u$ odnosu na šesti razred (Puzić, Baranović,
Doolan, 2011: 335-358). U istraživanju s temom Školska klima - teorijska načela $i$ istraživanje s motrišta učenika, nastavnika $i$ roditelja glavni je cilj bio pronaći odgovarajuću metodu, odnosno upitnik za provođenje istraživanja. Upitnik na kojem je provedena kvantitativna provjera pomogao je pri ocjeni kvalitete $\mathrm{u}$ pet područja školske klime u jednoj gimnaziji. Disperzivna analiza $u$ jednom čimbeniku otkrila je razlike u ocjenama učenika, nastavnika i roditelja za pet područja. Usporedivši prosječne odgovore tih triju skupina ispitanika, moglo se zaključiti da su najzadovoljniji sa svim područjima školske klime nastavnici. Proizašlo je da su roditelji nešto manje zadovoljni. Najveće nezadovoljstvo postoji među učenicima. Dobiveni bi rezultati u budućnosti mogli biti temelj za daljnje istraživanje u ovom području (Kuntarova, 2009: 183-189). U Puli 2013. godine provedeno je među učiteljima razredne nastave u 24 osnovne škole Istarske županije istraživanje $\mathrm{s}$ temom Značaj razrednoga ozračja u građanskom odgoju i obrazovanju kako bi se ispitalo mišljenje učitelja o obilježjima razrednog ozračja, utjecaju razrednog ozračja na provođenje građanskog odgoja i obrazovanja te o učincima građanskog odgoja i obrazovanja na odnose u školi. Dobiveni rezultati pokazali su da je razredno ozračje tijekom provođenja tema iz građanskog odgoja i obrazovanja 
najčešće poticajno te se od uvođenja građanskog odgoja i obrazovanja u školi poboljšao odnos prema učenicima $\mathrm{S}$ posebnim potrebama, odnos među učenicima $i$ učiteljima te odnos među učenicima (Diković, 2013: 327-339). U istraživanju s temom Rizična ponašanja učenika srednje škole $i$ doživljaj kvalitete razredno-nastavnog ozračja rezultati su pokazali da učenici različitih razina rizičnog ponašanja različito doživljavaju sve važnije komponente razrednonastavnog ozračja (jasnoća pravila ponašanja, razina discipliniranosti $u$ razredu, dosljednost u sankcioniranju kršenja školskih pravila, kvaliteta odnosa među učenicima, kvaliteta odnosa između nastavnika i učenika te kvaliteta prostorija u kojima se obrazovni proces odvija). Zaključno, autorice upućuju na potrebu intenziviranja stručnog rada s učenicima rizičnog ponašanja $u$ srednjim školama $u$ svrhu podizanja kvalitete socijalne integracije tih učenika u školsko okruženje, što bi urodilo višestrukim pozitivnim učincima (prevencija poremećaja u ponašanju i smanjivanje disciplinskih problema u školama) (Bouillet, Bijedić, 2007: 113-132). Rezultati istraživanja provedenog u Zadru s temom Školska klima kao prediktor ranog prekida školovanja pokazali su da su čimbenici koji utječu na školsku klimu, a povezani su s nastavnikom i učenikom, u umjerenoj korelaciji s udjelom učenika koji rano prekidaju školovanje. Nastavnikov moral i disciplinska klima u slaboj su korelaciji s tim istim udjelom. Najčvršća je povezanost utvrđena između učenikovih i nastavnikovih čimbenika koji utječu na školsku klimu; ona je ujedno pozitivna. Navedeni rezultati sugeriraju da nastavnikovi i učenikovi čimbenici u manjoj mjeri ometaju učenje i nastoje spriječiti rano prekidanje školovanja (Ozmsul, 2016: 491-517). U istraživanju s temom Poduzetnički poriv nastavnika osnovnih škola u Republici Hrvatskoj pretpostavilo se da će nastavnici koji sebe percipiraju kao osobe $\mathrm{s}$ poduzetničkim porivom efikasnije ostvarivati razvoj poduzetničke kompetencije kod učenika. Provedeno je empirijsko istraživanje na uzorku od 466 predmetnih nastavnika u 23 osnovne škole u Republici Hrvatskoj. Cilj je bio otkriti i razmotriti one dimenzije poduzetničkog poriva koje su se pokazale značajnim na upitniku formiranom u skali s 42 tvrdnje strukturirane u pet podskala koje upućuju na pet dimenzija poduzetničkog poriva osnovnoškolskih nastavnika. Primjenom deskriptivne statistike u radu su se interpretirali rezultati s obzirom na temeljne varijable ispitanika (spol, radni staž i nastavni predmet). Posebno su se razmatrale tri dimenzije poduzetničkog poriva osnovnoškolskih nastavnika s pedagoškog gledišta, a to su 
Đ. Hlapčić, Povezanost samopoštovanja nastavnika s procjenom školskog ozračja

usmjerenost prema inovativnosti i proaktivnosti, samopoštovanje i usmjerenost prema postignuću. Pokazalo se da osnovnoškolski nastavnici iskazuju visok stupanj samoprocjene dimenzija poduzetničkog poriva u nastavnom, školskom, izvannastavnom i izvanškolskom radu, i to najviši stupanj prema proaktivnosti i inovativnosti te usmjerenosti prema postignuću, a zatim prema samopoštovanju. Osnovnoškolski nastavnici pokazuju opće odlike za ostvarenje poduzetničke kulture u školi i primjenu poduzetničke pedagogije (Vican, 2012: 13-19). Istraživanje provedeno 2013. godine s temom Adolescentska stvarna $i$ virtualna prijateljstva analiziralo je odnos između realnih i virtualnih adolescentskih prijateljstava te nekih njihovih individualnih osobina (sramežljivost, usamljenost i samopoštovanje) i percipirane kvalitete odnosa s roditeljima, prijateljima $i$ nastavnicima te osjećaja

\section{ISPITANICI I METODE}

\section{Ustroj studije}

Ispitivanje je provedeno kao presječna studija (Ivanković i sur. 1988).

\section{Ispitanici}

Ispitanici su bili nastavnici Srednje škole Čakovec i Medicinske škole Varaždin. Ukupno je ispitano 97 nastavnika. Prije ispitivanja dobivene su suglasnosti pripadnosti školi i školskog uspjeha. Korelacijskom analizom utvrđena je pozitivna povezanost između socijalne podrške obitelji, prijatelja i nastavnika, osjećaja pripadnosti školi, boljeg školskog uspjeha i odnosa sa stvarnim prijateljima. No, što su učenici usamljeniji i što im je samopoštovanje niže, podrška obitelji slabija, a školski uspjeh lošiji, njihove su interakcije $\mathrm{s}$ virtualnim prijateljima intenzivnije. Višestruke regresijske analize pokazuju da pozitivne interakcije sa stvarnim prijateljima imaju djevojke te učenici koji osjećaju veću pripadnost školi, a negativne interakcije imaju učenici nižeg samopoštovanja i oni koji osjećaju manju pripadnost školi. S virtualnim prijateljima pozitivne reakcije imaju učenici koji dobivaju podršku od stvarnih prijatelja, a o većem intenzitetu negativnih interakcija izvještavaju dječaci te učenici koji su usamljeni i imaju niže samopoštovanje (Bilić, 2013: 1-16).

ravnatelja obiju škola i dozvola Etičkog povjerenstva Medicinskog fakulteta $\mathrm{u}$ Osijeku. Ispitanicima su podijeljeni informativni pristanci na kojima su svojim potpisima pristali sudjelovati u provođenju istraživanja. Svi ispitanici potpisali su obaviješteni pristanak. 


\section{Metode}

Za potrebe ovog istraživanja provedenog $\mathrm{u}$ Srednjoj školi Čakovec i Medicinskoj školi Varaždin koristila se anketa od triju dijelova. Prvi dio ankete sadržavao je demografske podatke: spol, duljinu radnog staža u nastavi (otvoreno pitanje), dob (otvoreno pitanje), mjesto rada (Srednja škola Čakovec i Medicinska škola Varaždin) i mjesto prebivališta (otvoreno pitanje). Drugi je dio ankete sadržavao Hrvatski upitnik školske klime za nastavnike, autorica Velki, KuterovacJagodić, sastavljen od osamnaest tvrdnji s odgovorima u obliku Likertove skale (1. izrazito se slažem; 2. slažem se; 3 . niti se slažem niti se ne slažem; 4. ne slažem se; 5. izrazito se ne slažem). Treći je dio ankete bila Rosenbergova skala samopoštovanja koja sadrži deset tvrdnji o stavovima i osjećajima o samom sebi $\mathrm{s}$ mogućim odgovorima u obliku Likertove skale: (1. u potpunosti se slažem - 1 bod; 2. slažem se - 2 boda; 3 . ne slažem se - 3 boda; 4. u potpunosti se ne slažem - 4 boda).

\section{REZULTATI}

\section{Osnovna obilježja ispitanika}

Istraživanje je provedeno na 97 ispitanika među kojima je 70 (72 \%) muškaraca i 27 (28 \%) žena. Iz Srednje škole Čakovec

\section{Statističke metode}

Kategorijski podatci predstavljeni su apsolutnim i relativnim frekvencijama. Numerički podatci opisani su medijanom i granicama interkvartilnog raspona. Normalnost raspodjele numeričkih varijabli testirana je Shapiro-Wilkovim testom. Razlike numeričkih varijabli, a zbog odstupanja od normalne raspodjele, testirane su Mann-Whitneyjevim U testom. Razlike numeričkih varijabli u tri i više nezavisnih skupina, a zbog odstupanja od normalne raspodjele, testirane su KruskalWallisovim testom. Ocjena povezanosti Rosenbergove skale samopoštovanja i nastavničke ocjene školske klime prikazana je Spearmanovim koeficijentom korelacije $\rho$ (Rho) (x). Sve su P vrijednosti dvostrane. Razina značajnosti postavljena je na Alpha $=0,05$. Za statističku analizu korišten je statistički program MedCalcStastiscical Software ver. 17.8.2 (MedCalc Software bvba, Ostend, Belgium; http://www.medcalc.org; 2017.) (Marušić i sur. 2008).

ispitanika je $56(58 \%)$. S obzirom na mjesto prebivališta, u gradu živi $63(65 \%)$ ispitanika (Tablica 1). 
Đ. Hlapčić, Povezanost samopoštovanja nastavnika s procjenom školskog ozračja

Tablica 1. Ispitanici u odnosu na spol, mjesto rada i prebivalište

\begin{tabular}{|c|c|}
\hline & broj $(\%)$ ispitanika \\
\hline \multicolumn{2}{|l|}{ spol } \\
\hline muškarci & $70(72)$ \\
\hline žene & $27(28)$ \\
\hline \multicolumn{2}{|l|}{ srednja škola } \\
\hline Srednja škola Čakovec & $56(58)$ \\
\hline Medicinska škola Varaždin & $41(42)$ \\
\hline \multicolumn{2}{|l|}{ mjesto prebivališta } \\
\hline selo & $34(35)$ \\
\hline grad & $63(65)$ \\
\hline ukupno & $97(100)$ \\
\hline
\end{tabular}

Medijan dobi ispitanika je 34 godine (interkvartilnog raspona od 30 do 42 godine) u rasponu od 23 do 65 godina, s rasponom duljine radnog staža od 1 do 30 godina (Tablica 2).

Tablica 2. Medijan dobi i duljine radnog staža

\begin{tabular}{ll}
\hline & $\begin{array}{l}\text { medijan } \\
\text { (interkvartilni raspon) }\end{array}$ \\
\hline dob ispitanika(godine) & $34(30-42)$ \\
duljina radnog staža(godine) & $5(3-12,5)$ \\
\hline
\end{tabular}

S obzirom na mjesto stanovanja, ispitanici su većinom iz Varaždina i Čakovca, dok je manji broj ispitanika iz ostalih mjesta Međimurske županije (Slika 1). 


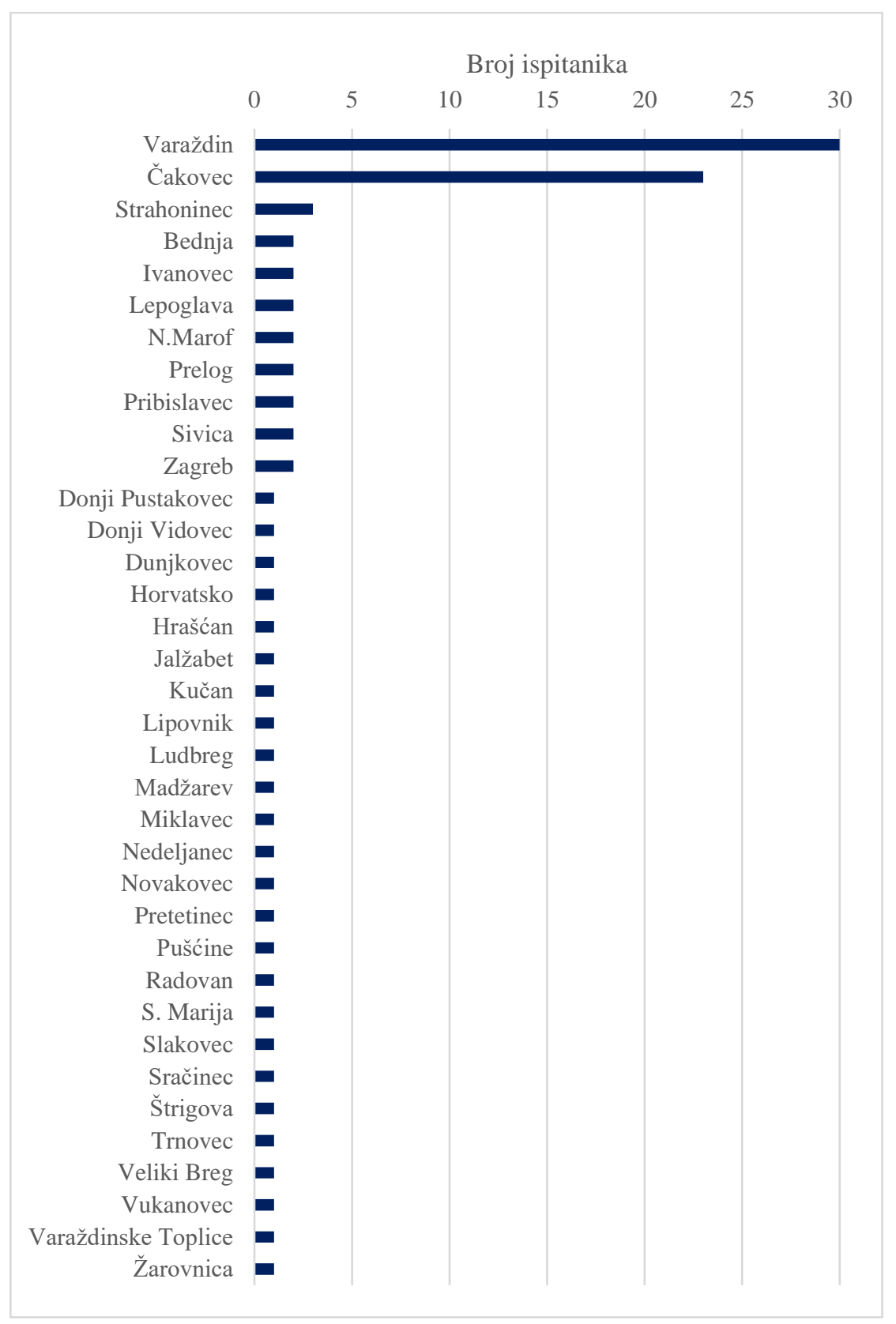

Slika 1. Raspodjela ispitanika prema mjestu stanovanja

\section{Hrvatski upitnik školske klime za nastavnike}

Školska klima za nastavnike ispitana je upitnikom s 18 čestica. Dobivena je visoka pouzdanost unutarnje konzistencije (Cronbach alfa za cijelu skalu iznosi 0,839). Da je njihova škola sigurno mjesto za rad, izrazito se slaže $44 \quad(45 \%)$ ispitanika, dok se samo jedan ispitanik s tom tvrdnjom ne slaže. S tvrdnjom da imaju dovoljno prilika za učenje novih metoda poučavanja, ne slaže se $11(11 \%)$ ispitanika, a neodlučno ih je 17 (18\%). S tvrdnjom da učenici imaju povjerenje $u$ 
Đ. Hlapčić, Povezanost samopoštovanja nastavnika s procjenom školskog ozračja

nastavnike slaže se $59(61 \%)$ ispitanika, kao i s tvrdnjom da su sposobni zaustaviti nasilničko ponašanje među učenicima. Svi se ispitanici ili izrazito slažu ili slažu da pokazuju poštovanje prema učenicima. $\mathrm{Ne}$ slažu se $2(2 \%)$ ispitanika, a njih $18(19 \%)$ neutralno je s obzirom na tvrdnju imaju li djelatnici škole u kojoj rade povjerenje $\mathrm{u}$ njihove profesionalne procjene (Tablica 3 ).

Tablica 3. Procjena školskog ozračja za nastavnike (1/3)

\begin{tabular}{|c|c|c|c|c|c|c|}
\hline & \multicolumn{6}{|c|}{ broj (\%) ispitanika } \\
\hline & $\begin{array}{l}\text { Izrazit } \\
\text { o se } \\
\text { slaže } \\
\text { m. }\end{array}$ & $\begin{array}{l}\text { Slaže } \\
\text { m se. }\end{array}$ & $\begin{array}{l}\text { Niti se } \\
\text { slažem niti } \\
\text { se ne } \\
\text { slažem. }\end{array}$ & $\begin{array}{l}\mathrm{Ne} \\
\text { slaže } \\
\text { m se. }\end{array}$ & $\begin{array}{l}\text { Izrazito } \\
\text { se ne } \\
\text { slažem. }\end{array}$ & ukupno \\
\hline $\begin{array}{l}\text { Ova škola sigurno je mjesto za } \\
\text { rad. }\end{array}$ & $44(45)$ & $44(45)$ & $8(8)$ & $1(1)$ & 0 & $97(100)$ \\
\hline $\begin{array}{l}\text { Imam dovoljno prilika za učenje } \\
\text { novih metoda poučavanja. }\end{array}$ & $23(24)$ & $46(47)$ & $17(18)$ & $11(11)$ & 0 & $97(100)$ \\
\hline $\begin{array}{l}\text { Učenici ove škole imaju } \\
\text { povjerenje u nastavnike. }\end{array}$ & $14(14)$ & $59(61)$ & $22(23)$ & $2(2)$ & 0 & $97(100)$ \\
\hline $\begin{array}{l}\text { Sposoban/a sam zaustaviti } \\
\text { nasilničko ponašanje među } \\
\text { učenicima. }\end{array}$ & $10(10)$ & $59(61)$ & $27(28)$ & $1(1)$ & 0 & $97(100)$ \\
\hline $\begin{array}{l}\text { Pokazujem poštovanje prema } \\
\text { učenicima. }\end{array}$ & $41(42)$ & $56(58)$ & 0 & 0 & 0 & $97(100)$ \\
\hline $\begin{array}{l}\text { Djelatnici škole u kojoj radim } \\
\text { imaju povjerenje u moje } \\
\text { profesionalne procjene. }\end{array}$ & $13(13)$ & $64(66)$ & $18(19)$ & $2(2)$ & 0 & $97(100)$ \\
\hline
\end{tabular}

S tvrdnjom da razgovaraju s učenicima o problemima nasilja među djecom izrazito se slaže $15(15 \%)$ ispitanika, dok ih je 14 (14\%) ili neutralno ili se ne slaže ili pak se izrazito ne slaže. Da je nastavnicima u školi u kojoj rade izrazito stalo da učenici budu uspješni, navodi 30 (31\%) ispitanika, a $51(53 \%)$ ispitanik slaže se s tvrdnjom da neki nastavnici nisu fer prema svim učenicima u školi. Da se nastavnici u školi u kojoj rade trude dati podršku učenicima, slažu se $63(65 \%)$ ispitanika, dok ih je 11 (11\%) neutralno. 
$\mathrm{S}$ tvrdnjom da nastavnici u školi u kojoj rade pripremaju učenike da postanu produktivni građani, slaže se ili izrazito slaže $76(79 \%)$ ispitanika, dok ih je $21(21$ $\%)$ neutralan. Odlasku na posao većinom se raduje 71 (74\%) ispitanik (Tablica 4).

Tablica 4. Procjena školskog ozračja za nastavnike (2/3)

\begin{tabular}{|c|c|c|c|c|c|c|}
\hline & \multicolumn{6}{|c|}{ broj (\%) ispitanika } \\
\hline & $\begin{array}{l}\text { Izrazit } \\
\text { o se } \\
\text { slaže } \\
\text { m. }\end{array}$ & $\begin{array}{l}\text { Slaže } \\
\text { m se. }\end{array}$ & $\begin{array}{l}\text { Niti se } \\
\text { slažem niti } \\
\text { se ne } \\
\text { slažem. }\end{array}$ & $\begin{array}{l}\mathrm{Ne} \\
\text { slaže } \\
\text { m se. }\end{array}$ & $\begin{array}{l}\text { Izrazito } \\
\text { se ne } \\
\text { slažem. }\end{array}$ & ukupno \\
\hline $\begin{array}{lcc}\text { Razgovaram } & \mathrm{s} \text { učenicima o } \\
\text { problemima } & \text { nasilja među } \\
\text { djecom. } & & \end{array}$ & $15(15)$ & $68(70)$ & $12(12)$ & $1(1)$ & $1(1)$ & $97(100)$ \\
\hline $\begin{array}{l}\text { Nastavnicima u ovoj školi stalo } \\
\text { je da učenici budu uspješni. }\end{array}$ & $30(31)$ & $52(54)$ & $15(15)$ & 0 & 0 & $97(100)$ \\
\hline $\begin{array}{l}\text { Neki nastavnici nisu fer prema } \\
\text { svim učenicima u školi. }\end{array}$ & $1(1)$ & $51(53)$ & $28(29)$ & $16(16)$ & $1(1)$ & $97(100)$ \\
\hline $\begin{array}{l}\text { Nastavnici u ovoj školi trude se } \\
\text { dati podršku učenicima. }\end{array}$ & $22(23)$ & $63(65)$ & $11(11)$ & $1(1)$ & 0 & $97(100)$ \\
\hline $\begin{array}{l}\text { U ovoj školi pripremamo } \\
\text { učenike da postanu produktivni } \\
\text { građani. }\end{array}$ & $19(20)$ & $57(59)$ & $21(21)$ & 0 & 0 & $97(100)$ \\
\hline $\begin{array}{l}\text { Većinom se radujem odlasku na } \\
\text { posao. }\end{array}$ & $22(23)$ & $49(51)$ & $20(21)$ & $6(6)$ & 0 & $97(100)$ \\
\hline
\end{tabular}

Većinu roditelja/skrbnika svojih učenika nikada nije upoznalo 13 (13\%) ispitanika. S tvrdnjom da učenici njihove škole nisu motivirani za učenje, slaže se 8 (8 \%) ispitanika, a 43 (44\%) ih je neutralno. Većina ispitanika osjeća da pripada školi u kojoj radi, kao i da se u školi uvijek ima komu obratiti za savjet ili pomoć ako je potrebno. Da su odnosi među djelatnicima njihove škole korektni i kolegijalni, slaže se $8(8 \%)$ ispitanika, a njih je 18 $(19 \%)$ neutralno. Izrazito se slaže ili slaže s tvrdnjom da su odnosu između nastavnika i učenika njihove škole skladni i prijateljski 70 (72 \%) ispitanika, dok ih je 27 (28\%) neutralno (Tablica 5). 
Đ. Hlapčić, Povezanost samopoštovanja nastavnika s procjenom školskog ozračja

Tablica 5. Procjena školskog ozračja za nastavnike (3/3)

\begin{tabular}{|l|l|l|l|l|l|l|}
\hline \multicolumn{2}{|l|}{} & \multicolumn{2}{|l|}{ broj (\%) ispitanika } \\
\cline { 2 - 7 } & $\begin{array}{l}\text { Izrazito } \\
\text { se } \\
\text { slažem. }\end{array}$ & $\begin{array}{l}\text { Slažem } \\
\text { se. }\end{array}$ & $\begin{array}{l}\text { Niti se } \\
\text { slažem } \\
\text { niti se } \\
\text { ne } \\
\text { slažem. }\end{array}$ & $\begin{array}{l}\text { Ne } \\
\text { slaže } \\
\text { m se. }\end{array}$ & $\begin{array}{l}\text { lzrazit } \\
\text { o se } \\
\text { ne } \\
\text { slaže } \\
\text { m. }\end{array}$ & ukupno \\
\hline $\begin{array}{l}\text { Upoznao/la sam većinu roditelja/ } \\
\text { skrbnika svojih učenika. }\end{array}$ & $10(10)$ & $28(29)$ & $17(18)$ & $29(30)$ & $13(13)$ & $97(100)$ \\
\hline $\begin{array}{l}\text { Učenici ove škole nisu motivirani } \\
\text { za učenje. }\end{array}$ & 0 & $8(8)$ & $43(44)$ & $40(41)$ & $6(6)$ & $97(100)$ \\
\hline $\begin{array}{l}\text { Osjećam da pripadam školi u } \\
\text { kojoj radim. }\end{array}$ & $16(16)$ & $60(62)$ & $20(21)$ & $1(1)$ & 0 & $97(100)$ \\
\hline $\begin{array}{l}\text { U školi se uvijek imam komu } \\
\text { obratiti za savjet ili pomoć ako je } \\
\text { to potrebno. }\end{array}$ & $20(21)$ & $51(53)$ & $18(19)$ & $8(8)$ & 0 & $97(100)$ \\
\hline $\begin{array}{l}\text { Odnosi među djelatnicima ove } \\
\text { škole korektni su i kolegijalni. }\end{array}$ & $5(5)$ & $44(45)$ & $37(38)$ & $10(10)$ & $1(1)$ & $97(100)$ \\
\hline $\begin{array}{l}\text { Odnosi između nastavnika i } \\
\text { učenika ove škole skladni su i } \\
\text { prijateljski. }\end{array}$ & $6(6)$ & $64(66)$ & $27(28)$ & 0 & 0 & $97(100)$ \\
\hline
\end{tabular}

Raspon cijele skale ocjene školske klime nastavnika u rasponu je od 18 do 75 , a viši rezultat upućuje da nastavnici percipiraju negativniju školsku klimu. Medijan cijele skale je 40 (interkvartilnog raspona od 36 do 43). Nešto je negativnija percepcija žena, ispitanika u dobi od 41 do 50 godina, ispitanika s više godina radnog staža te ispitanika koji rade u Srednjoj školi
Čakovec, no bez statistički značajne razlike. Značajno negativniju percepciju imaju ispitanici koji žive na selu, medijana 42 (interkvartilnog raspona od 37 do 47) u odnosu na ispitanike koji žive u gradu, medijana 39 (interkvartilnog raspona od 35 do 42) (Mann Whitneyjev U test, $\mathrm{P}=0,02$ ) (Tablica 6).Tablica 6. Ocjena školske klime u odnosu na opća obilježja ispitanika 


\begin{tabular}{|c|c|c|}
\hline & $\begin{array}{l}\text { medijan } \\
\text { (interkvartilni raspon) }\end{array}$ & $\mathrm{P}$ vrijednost \\
\hline \multicolumn{3}{|l|}{ spol } \\
\hline muškarci & $39(36-43)$ & \multirow{2}{*}{$0,16^{*}$} \\
\hline žene & $41(36-47)$ & \\
\hline \multicolumn{3}{|l|}{ dob ispitanika } \\
\hline do 30 godina $(n=27)$ & $37(34-42)$ & \multirow{4}{*}{$0,07^{\dagger}$} \\
\hline $31-40(n=44)$ & $41(37-43)$ & \\
\hline $41-50(n=14)$ & $42(35-47)$ & \\
\hline 51 i više $(n=12)$ & $38(33-41)$ & \\
\hline \multicolumn{3}{|l|}{ duljina radnog staža } \\
\hline do 5 godina $(n=54)$ & $39(35-43)$ & \multirow{3}{*}{$0,20^{\dagger}$} \\
\hline $6-15$ godina $(n=28)$ & $42(37-47)$ & \\
\hline 16 i više godina $(n=15)$ & $38(36-42)$ & \\
\hline \multicolumn{3}{|l|}{ srednja škola } \\
\hline Srednja škola Čakovec & $40(36-45)$ & \multirow{2}{*}{$0,11^{*}$} \\
\hline Medicinska škola Varaždin & $38(35-42)$ & \\
\hline \multicolumn{3}{|l|}{ mjesto prebivališta } \\
\hline selo & $42(37-47)$ & \multirow{2}{*}{$0,02^{*}$} \\
\hline grad & $39(35-42)$ & \\
\hline ukupna ocjena školske klime & $40(36-43)$ & \\
\hline
\end{tabular}

"MannWhitney U test; ${ }^{\dagger}$ KruskalWallis test

\section{Rosenbergova skala samopoštovanja}

Skalu samopoštovanja čini 10 čestica. vrijeme pomisle kako nisu dobri ni u čemu.

Pouzdanost unutarnje konzistencije,

Cronbach alfa za cijelu skalu, iznosi 0,598.

Samim sobom u potpunosti je zadovoljan

$31(32 \%)$ ispitanik, a $23(24 \%)$ ispitanika

slažu se $\mathrm{s}$ tvrdnjom da $\mathrm{s}$ vremena na
$\mathrm{S}$ tvrdnjom da imaju puno dobrih osobina potpuno se slaže 20 (21\%) ispitanika, 23 (24\%) ispitanika slažu se da su sposobni raditi stvari podjednako dobro kao i većina ljudi, a njih $26(27 \%)$ u potpunosti se 
Đ. Hlapčić, Povezanost samopoštovanja nastavnika s procjenom školskog ozračja

slažu s tvrdnjom da su osobe koje vrijede, bar kao većina ljudi. Da nemaju puno toga na što bi bili ponosni, slaže se $10(10 \%)$ ispitanika, a njih $18(19 \%)$ u potpunosti se slažu ili pak samo slažu da se s vremena na vrijeme osjećaju beskorisno. Većina ispitanika, njih 62 (64\%), slaže se u potpunosti ili pak samo slaže s tvrdnjom da

\section{Tablica 7. Ispitanici prema skali samopoštovanja}

\begin{tabular}{|c|c|c|c|c|c|}
\hline & \multicolumn{5}{|c|}{ broj (\%) ispitanika } \\
\hline & $\begin{array}{l}\text { U } \\
\text { potpunos } \\
\text { ti se } \\
\text { slažem. }\end{array}$ & $\begin{array}{l}\text { Slažem } \\
\text { se. }\end{array}$ & $\begin{array}{l}\mathrm{Ne} \\
\text { slažem } \\
\text { se. }\end{array}$ & $\begin{array}{l}\text { U } \\
\text { potpuno } \\
\text { sti se ne } \\
\text { slažem. }\end{array}$ & ukupno \\
\hline $\begin{array}{l}\text { U suštini, zadovoljan/na sam } \\
\text { samim/samom sobom. }\end{array}$ & $31(32)$ & $60(62)$ & $6(6)$ & 0 & $97(100)$ \\
\hline $\begin{array}{l}\text { * S vremena na vrijeme pomislim da } \\
\text { nisam dobar/a ni u čemu. }\end{array}$ & $2(2)$ & $23(24)$ & $54(56)$ & 18(19) & $97(100)$ \\
\hline Mislim da imam puno dobrih osobina. & $20(21)$ & $70(72)$ & $6(6)$ & $1(1)$ & $97(100)$ \\
\hline $\begin{array}{l}\text { Sposoban/na sam raditi stvari } \\
\text { podjednako dobro kao većina ljudi. }\end{array}$ & $23(24)$ & $69(71)$ & $4(4)$ & $1(1)$ & $97(100)$ \\
\hline $\begin{array}{l}\text { * Mislim da nemam puno toga na šta } \\
\text { bih bio/la ponosan/a. }\end{array}$ & $1(1)$ & $9(9)$ & $57(59)$ & $30(31)$ & $97(100)$ \\
\hline $\begin{array}{l}\text { * } \mathrm{S} \text { vremena na vrijeme osjećam se } \\
\text { beskorisno. }\end{array}$ & $2(2)$ & $16(17)$ & $52(54)$ & $27(28)$ & $97(100)$ \\
\hline $\begin{array}{l}\text { Mislim da sam osoba koja vrijedi, bar } \\
\text { kao većina drugih ljudi. }\end{array}$ & $26(27)$ & $69(71)$ & $2(2)$ & 0 & $97(100)$ \\
\hline $\begin{array}{l}\text { * Volio/voljela bih imati više } \\
\text { samopoštovanja. }\end{array}$ & $12(12)$ & $50(52)$ & $26(27)$ & $9(9)$ & $97(100)$ \\
\hline $\begin{array}{l}\text { * Sve u svemu, sklon/a sam mišljenju } \\
\text { da sam potpun neuspjeh. }\end{array}$ & 0 & $3(3)$ & $29(30)$ & $65(67)$ & $97(100)$ \\
\hline Imam pozitivan stav o sebi. & $23(24)$ & $68(70)$ & $6(6)$ & 0 & $97(100)$ \\
\hline
\end{tabular}

*obrnuto bodovanje 
Raspon je ocjena skale samopoštovanja od 10 do 40, a niži rezultat upućuje na višu razinu samopoštovanja. Medijan ukupne skale samopoštovanja je 19 (interkvartilnog raspona od 16 do 21 ).
Nema značajne razlike u samopoštovanju u odnosu na spol, dob, godine radnog staža, škole u kojoj rade ili pak prema mjestu prebivališta (Tablica 8 ).

Tablica 8. Ocjena skale samopoštovanja u odnosu na opća obilježja ispitanika

\begin{tabular}{|c|c|c|}
\hline & $\begin{array}{l}\text { medijan } \\
\text { (interkvartilni raspon) }\end{array}$ & $\mathrm{P}$ vrijednost \\
\hline \multicolumn{3}{|l|}{ spol } \\
\hline muškarci & $19(17-21)$ & \multirow{2}{*}{$0,47^{*}$} \\
\hline žene & $20(16-22)$ & \\
\hline \multicolumn{3}{|l|}{ dob ispitanika } \\
\hline do 30 godina $(n=27)$ & $19(16-21)$ & \multirow{4}{*}{$0,17^{\dagger}$} \\
\hline $31-40(n=44)$ & $20(18-22)$ & \\
\hline $41-50(n=14)$ & $19(14-20)$ & \\
\hline 51 i više $(n=12)$ & $18(14-21)$ & \\
\hline \multicolumn{3}{|l|}{ duljina radnog staža } \\
\hline do 5 godina $(n=54)$ & $19(16-21)$ & \multirow{3}{*}{$0,41^{\dagger}$} \\
\hline $6-15$ godina $(n=28)$ & $20(17-24)$ & \\
\hline 16 i više godina $(n=15)$ & $19(16-20)$ & \\
\hline \multicolumn{3}{|l|}{ srednja škola } \\
\hline Srednja škola Čakovec & $20(16-21)$ & \multirow{2}{*}{$0,34^{*}$} \\
\hline Medicinska škola Varaždin & $19(16-21)$ & \\
\hline \multicolumn{3}{|l|}{ mjesto prebivališta } \\
\hline selo & $20(16-22)$ & \multirow{2}{*}{$0,33^{*}$} \\
\hline grad & $19(16-21)$ & \\
\hline ukupna skala samopoštovanja & $19(16-21)$ & \\
\hline
\end{tabular}

*MannWhitney U test; ${ }^{\dagger}$ KruskalWallis test

\section{Povezanost samopoštovanja s ocjenom školskog ozračja}

Spearmanovim koeficijentom korelacije ocijenili smo povezanost samopoštovanja s ocjenom školskog ozračja. Na cijelom uzorku ispitanika ispitanici $\mathrm{s}$ većim samopoštovanjem imaju percepciju negativnije školske klime i obratno, oni s manjim samopoštovanjem imaju percepciju pozitivnije školske klime 
Đ. Hlapčić, Povezanost samopoštovanja nastavnika s procjenom školskog ozračja

( $\rho=0,466 \mathrm{P}<0,001)$. I u skupini žena i u skupini muškaraca postoji značajna povezanost, ali je ona jača u skupini žena ( $\rho=0,664 \mathrm{P}<0,001)$, znači žene $\mathrm{s}$ većim samopoštovanjem imaju percepciju negativnije školske klime. Najjača povezanost samopoštovanja i ocjene školske klime u dobi je do 30 godina $(\rho=0,756 \quad \mathrm{P}<0,001), \quad$ dok $\quad \mathrm{u} \quad$ ostalim dobnim skupinama nema značajne povezanosti samopoštovanja $\mathrm{s}$ ocjenom školskog ozračja. Što se tiče povezanosti samopoštovanja i godina radnog staža, u skupini ispitanika sa 16 i više godina radnog staža nema značajnije povezanosti, dok je u ostalim dvjema skupinama ta povezanost bitna, nešto jača u skupini ispitanika koji rade od 6 do 15 godina $(\rho=0,559 \mathrm{P}=0,002) . \mathrm{S}$ obzirom na mjesto stanovanja, značajna je povezanost samopoštovanja s ocjenom školskog ozračja i kod ispitanika iz grada i sa sela, no veza je nešto jača kod ispitanika sa sela $(\rho=0,499 \mathrm{P}<0,001)($ Tablica 9$)$.

Tablica 9. Ocjena povezanosti samopoštovanja s ocjenom školskog ozračja Spearmanovim koeficijentom korelacije

\section{Povezanost samopoštovanja s ocjenom školskog ozračja}

\begin{tabular}{|c|c|c|}
\hline \multirow[b]{2}{*}{ ukupno (svi ispitanici) } & $\begin{array}{l}\text { Spearmanov koeficijent } \\
\text { korelacije (Rho) }\end{array}$ & $\mathrm{P}$ vrijednost \\
\hline & 0,466 & $<0,001$ \\
\hline \multicolumn{3}{|l|}{ spol } \\
\hline muškarci & 0,348 & $\mathbf{0 , 0 0 3}$ \\
\hline žene & 0,664 & $<0,001$ \\
\hline \multicolumn{3}{|l|}{ dob ispitanika } \\
\hline do 30 godina $(n=27)$ & 0,756 & $<0,001$ \\
\hline $31-40(n=44)$ & 0,264 & 0,08 \\
\hline $41-50(n=14)$ & 0,377 & 0,18 \\
\hline 51 i više $(n=12)$ & 0,468 & 0,13 \\
\hline
\end{tabular}

duljina radnog staža
do 5 godina $(\mathrm{n}=54)$
0,382
0,004
$6-15$ godina $(\mathrm{n}=28)$
0,559
0,002
16 i više godina $(n=15)$
0,335
0,22 
mjesto prebivališta

$$
\text { selo }
$$

$\operatorname{grad}$

0,421

0,001

\section{RASPRAVA}

Istraživanje o ulozi samopoštovanja nastavnika u školskoj klimi medicinske škole provedeno među nastavnicima Srednje škole Čakovec i Medicinske škole Varaždin pokazalo je da ispitanici s većim samopoštovanjem negativnije percipiraju školsku klimu i obratno, oni s manjim samopoštovanjem pozitivnije percipiraju školsku klimu. Iz ovog proizlazi da osobe s većim samopoštovanjem imaju općenito više kriterije, žele manji radni pritisak, više komfora i više prilika za učenje i inovativnost $\mathrm{u}$ radu.

Jedan je od preduvjeta uspješnog nastavnog rada i stvaranje ,određene psihološke atmosfere za rad, povoljne radne situacije." Najvažniju ulogu u stvaranju povoljnih situacija u nastavi koje će rezultirati pozitivnim, aktivnim odnosom učenika prema nastavnom radu, ima nastavnik kao organizator nastavnog procesa iako takve situacije ovise i o mnogim drugim čimbenicima. Osim vanjskih čimbenika od izuzetne su važnosti i unutarnji čimbenici koji osim nastavnikove pedagoške stručnosti podrazumijevaju i njegovu sposobnost poniranja u suptilne zakonitosti procesa obrazovanja i dobrih međuljudskih odnosa. Nastavnik s takvim sposobnostima ima visoku razinu samopoštovanja. Rezultati ovog istraživanja pokazali su percepciju nastavnika o školskoj klimi i njihovu procjenu vlastitog mišljenja o sebi. U sljedećim istraživanjima trebalo bi voditi računa o ispitanikovim, eventualnim socijalno poželjnim odgovorima te osmisliti istraživanje na način da se istražuje nastavnikova osviještenost o njegovu utjecaju na školsku klimu (bio on pozitivan ili negativan), a ne samo njegova percepcija te klime.

Najdojmljiviji je nalaz istraživanja u Zagrebu bio da je klima u osnovnim školama povoljnija $u$ odnosu na druge tipove škola, što se osobito očituje procjenom većeg stupnja inovativnosti i fizičkog komfora te iskazivanjem manjeg radnog pritiska (Domović, 2003).

Istraživanje u Zagrebu pokazuje da visok postotak učitelja i nastavnika procjenjuje da su bili involvirani u izradu godišnjeg plana škole $(83.5 \%)$ te da imaju visok stupanj autonomije u osmišljavanju i izvođenju nastave, uz neznatan doživljaj 
kontrole. $\mathrm{Na}$ primjer, svega $16.1 \%$ nastavnika procjenjuje da ih se u školi previše nadzire. Nadalje, više od četiri petine nastavnika izjavljuju da mogu samostalno rješavati probleme, a gotovo 90\% nastavnika uglavnom se ili u potpunosti ohrabruje da primjenjuju nove metode rada. Više od trećine nastavnika smatra da se od njih očekuje da stalno uče i inoviraju svoj rad, a postoji i velika otvorenost prema promjenama. Ovi podatci sugeriraju da je u promatranim školama radni kontekst poticajan, što se može tumačiti kao dobra pretpostavka za rad nastavnika i inoviranje njihova rada. Istovremeno, s druge strane, nastavnici neke organizacijske značajke procjenjuju manje povoljnima. Tako, primjerice, trećina učitelja i nastavnika smatra da ne može otvoreno iznositi kritičke primjedbe na rad školi (Baranović, Domović, Štirbić, 2006: 485-504). Ovaj odgovor moguće je tumačiti postojanjem implicitne kulture koja u značajnoj mjeri determinira ponašanje u školi.

Sociodemografska obilježja imaju utjecaj u procjeni nastavničkog samopoštovanja i školske klime. Rezultati pokazuju da žene negativnije procjenjuju školsku klimu. Također, žene s većim samopoštovanjem negativnije procjenjuju školsku klimu. S obzirom na opća demografska obilježja, od sveukupno 97 ispitanika samo je 27 žena te bi u sljedećem istraživanju trebalo imati $u$ vidu da ispitanici po mogućnosti budu približno istospolno zastupljeni. Također, školsku klimu negativnije procjenjuju ispitanici dobi od 41 do 50 godina života, $s$ više godina radnog staža i ispitanici iz Srednje škole Čakovec, ali bez statistički značajne razlike. Vjerojatni razlog iskustvena je usporedba iz njihova gledišta, ali i način rada kojim učenje polako, ali sigurno postaje usmjereno na učenika, a ne na učitelja te potreba nastavničke fleksibilnosti koja, nažalost, često nedostaje. Preferira se aktivno, iskustveno učenje, učenicima se pomaže da urade sami, a ne da samo sjede i slušaju. Nove metode rada zahtijevaju kontinuiran rad i učenje, sposobnost prilagodbe i stalnu aktivnost u osmišljavanju inovacija kojim učenika treba zaokupiti i zainteresirati. Budući da je veći broj ispitanika iz Srednje škole Čakovec, rezultat se mogao pretpostavljati.

Rezultati istraživanja provedenog 2013. godine kojem je cilj, među ostalim, bio ispitati u kojoj mjeri sociodemografska obilježja učitelja, razlozi izbora učiteljske profesije i razina samopoštovanja predviđaju pojavljivanje profesionalnog sagorijevanja na poslu kod učitelja osnovne škole pokazuju da sociodemografska obilježja, razlozi izbora učiteljske profesije i razina samopoštovanja značajno predviđaju 
učiteljsko sagorijevanje. Pokazalo se da su muški učitelji, učitelji iz matičnih škola, učitelji koji imaju prebivalište u gradu, učitelji koji nisu zadovoljni izborom učiteljske profesije, učitelji koji očekuju da učiteljska profesija pruža mnogo vremena za obitelj i sigurnost posla, učitelji kojima je učiteljski studij bio drugi izbor studija, učitelji koji imaju nisku intrinzičnu motivaciju i nisku sposobnost poučavanja, učitelji koji smatraju da svojom profesijom imaju slab doprinos društvu te učitelji $\mathrm{s}$

\section{ZAKLJUČCI}

Na temelju provedenog istraživanja i dobivenih rezultata mogu se navesti sljedeći zaključci:

Nastavnici s većim samopoštovanjem negativnije, a nastavnici s manjim samopoštovanjem pozitivnije percipiraju školsku klimu

Žene negativnije percipiraju školsku klimu.

Nastavnici u dobi od 41 do 50 godina negativnije percipiraju školsku klimu.

Nastavnici s duljim radnim stažem negativnije percipiraju školsku klimu.

Negativniju percepciju školske klime imaju nastavnici koji žive na selu. niskim samopoštovanjem imaju veći rizik profesionalnog sagorijevanja na poslu (Kuzijev, Topolovčan, 2013: 125-144).

Cilj je istraživanja, među ostalim, bio utvrditi razlike nastavničkog samopoštovanja s obzirom na spol, mjesto prebivališta i duljinu staža. Rezultati su pokazali da nema značajne razlike. Kad se istraživanja bave temama kao što su samopoštovanje, treba imati odmak $u$ smislu eventualnih socijalno poželjnih odgovora bez obzira na anonimnost anketa.

Negativniju percepciju školske klime imaju nastavnici u Srednjoj školi Čakovec.

Nema razlike u nastavničkom samopoštovanju u odnosu na spol.

Nema razlike u nastavničkom samopoštovanju u odnosu na dob.

Nema razlike u nastavničkom samopoštovanju u odnosu na duljinu radnog staža.

Nema razlike u nastavničkom samopoštovanju s obzirom na mjesto prebivališta.

Nema razlike u nastavničkom samopoštovanju obzirom na mjesto rada. 
Đ. Hlapčić, Povezanost samopoštovanja nastavnika s procjenom školskog ozračja

\section{LITERATURA}

1. Domović, V. 2003. Školsko ozračje i učinkovitost škole. Jastrebarsko: Naklada Slap.

2. Božić, B. 2015. Stvarno i poželjno razredno ozračje u osnovnoj školi. Život $i$ škola: časopis za teoriju i praksu odgoja i obrazovanja 61/1.93-100.

3. Puzić, S., Baranović, B., Doolan, K. 2011. Školska klima i sukobi u školi. Sociologija $i$ prostor: časopis za istraživanja prostornoga i sociokulturnog razvoja. 49/3(191). 335358.

4. Vukasović, A. 1998. Pedagogija. Zagreb: Hrvatski katolički zbor.

5. Vlada Republike Hrvatske. 1999. Strategija odgojno-obrazovnog djelovanja. https://element.hr/artikli/file/963 (pristupljeno: 15. listopada 2021.)

6. Matijević, M. 1997. Didaktičke strategije i razredno-nastavno ozračje na početku obveznoga školovanja. Školski vjesnik: časopis za pedagoška i školska pitanja. 33-44.

7. Rijavec, M., Miljković, D. 2008. Razgovori sa zrcalom. Zagreb. IEP.

8. Kuzijev, J., Topolovčan, T. 2013. Uloga odabira učiteljske profesije i samopoštovanja o sagorijevanju učitelja u osnovnoj školi. Andragoški glasnik 31. 125-144.

9. Kuntarova, J. 2009. Školska klima-teorijska načela i istraživanje motrišta učenika, nastavnika i roditelja. Odgojne znanosti 17. 183-189.

10. Diković, M. 2013. Značaj razrednoga ozračja u građanskom odgoju i obrazovanju. Pedagogijska istraživanja 10. 327-339.

11. Bouillet, D., Bijedić, M. 2007. Rizična ponašanja učenika srednjih škola i doživljaj kvalitete razredno-nastavnog ozračja. Odgojne znanosti 9. 113-132.

12. Ozmsul, M. 2016. Školska klima kao prediktor ranog prekida školovanja. Hrvatski časopis za odgoj i obrazovanje 18. 491-517.

13. Vican, D. 2012. Poduzetnički poriv nastavnika osnovnih škola u Republici Hrvatskoj. Učenje za poduzetništvo,2. 13-19.

14. Bilić, V. 2013. Adolescentska stvarna i virtualna prijateljstva: Uloga socijalne podrške, nekih individualnih karakteristika i školskih varijabli. Hrvatska revija za rehabilitacijska istraživanja, 49. 1-16.

15. Ivanković, D. i sur. 1988. Osnove statističke analize za medicinare. Zagreb. Medicinski fakultet Sveučilišta u Zagrebu.

16. Marušić, M. i sur. 2008. Uvod u znanstveni rad u medicini. Zagreb. Medicinska naklada. 
17. Baranović, B., Domović, V., Štirbić, M. 2006. O aspektima školske klime u osnovnim školama u Hrvatskoj. Sociologija i prostor: časopis za istraživanje prostornoga $i$ sociokulturnog razvoja 174. 485-504.

\title{
SUMMARY \\ RELATIONSHIP BETWEEN TEACHER SELF-ESTEEM AND ASSESSMENT OF THE SCHOOL ATMOSPHERE
}

\begin{abstract}
Objectives: Examine the correlation between teachers' self-esteem and their evaluation of school atmosphere (school climate). Case: Respondents were teachers of the High School Čakovec and the Medical School Varaždin. A cross-sectional study was carried out, involving 97 teachers in total. An anonymous poll sheet was used, which consisted of three parts. The first part collected demographic data, the second consisted of Croatian School Climate Survey for Teachers, and the third of Rosenberg Self-Esteem Scale, which contains ten statements about attitudes and feelings about oneself. Category data were represented by absolute and relative frequencies. Numerical data were described using the arithmetic mean and, in cases of normal distribution, standard deviation. Cases of non-normal distribution were described using median and interquartile range boundaries. Differences in category variables were tested using chi-squared test and Fisher's exact test, if necessary. The normality of the distribution of numeric variables was tested using Shapiro-Wilk test. The differences of normally distributed numeric variables between two independent groups were tested using Student's $t$-test, while cases of non-normal distribution were tested using Mann-Whitney $U$ test. The differences of normally distributed numeric variables between three and more independent groups were tested using analysis of variance (ANOVA), whereas cases of non-normal distribution were tested using Kruskal-Wallis test. The correlation of normally distributed numeric variables was evaluated using Pearson's correlation coefficient (r), while cases of non-normal distribution were evaluated using Spearman's correlation coefficient (rho). Scale reliability was estimated using internal consistency coefficient (Cronbach Alpha). All P-values are two-sided. Significance level was set at Alpha $=0.05$. Results: Teachers with higher self-esteem evaluate school climate more negatively, while those with lower self-esteem evaluate it more positively. Conclusion: Teachers who have higherself-esteem have higher criteria, they seek challenges, lower working pressure and innovative working methods.
\end{abstract}

Key words: teachers, self-esteem, school climate 